\title{
A TV, os literatos e as Massas no Brasil João Freire Filho*
}

\section{RESUMO}

$O$ intuito deste artigo é esmiuçar as diferentes posturas da intelligentsia literária nacional interessada em controlar ou mediar a ascendência do meio de comunicação de maior penetração popular do pais. A partir da releitura de ensaios, cartas, crônicas e entrevistas (reunidas em livros ou ainda inéditas), tento demonstrar como a televisão foi adquirindo, entre nós, um lugar central no debate a respeito da natureza do público e do papel das artes e das letras na era (pós-)moderna.

\section{ABSTRACT}

The aim of this anticle is to investigate the different attitudes toward television that prevailed among Brazilian literany intelligentsia from 1950 to 1980. My main contention is that the nation's most popular entertainment became centrally important in shaping the intellectuals' views on the nature of the public, the role of the arts and letters, and the responsibilities of an educated elite in the (post)modern era. Their contradictony criticisms are surveyed in letters, interviews, biographies, newspapers and literany magazines. 
Equivoca-se quem imagina que a intelligentsia literária sempre encarou a TV como uma inexcedível ameaça para o indivíduo e a sociedade - "um tipo de aparato anticlássico de barbarização automática", na sintética definição do historiador inglês Patrick Brantlinger $(1983,251)$. Nos primeiros 30 anos de sua existência, o moderno dispositivo audiovisual foi conceituado de formas radicalmente discrepantes: inspirou, para uns, o pesadelo do esvaziamento do papel legislativo da elite intelectual tradicional; para outros, o sonho da intervenção criativa e política em um mercado profissional recém-aberto.

Não foram poucos os escritores e críticos que indiciaram a "máquina de fazer doidos" ("retardados"; "imbecis"; os diagnósticos variam) como causa e sintoma, ao mesmo tempo, do nosso declínio social e cultural; rechaçando o fatalismo dessas análises, previsões mais otimistas imaginaram lugares seguros, no amplo espectro da programação, para a expressão de pontos de vistas políticos suprimidos e para a emergência de uma alta cultura do vídeo (enraizada nos paradigmas historicamente legitimados da grande arte ou fomentada por uma pesquisa laboriosa sobre a linguagem específica do novo meio). Promessa bem-vinda de renovação artística, instrumento de conscientização das massas ou vírus de efeitos políticos e intelectuais altamente degenerativos, a televisão foi adquirindo, entre nós, um lugar central no debate a respeito da natureza do público e do papel das artes e das letras na vida (pós-)moderna.

106 O otimismo das primeiras especulações e teses acerca do "mais poderoso veículo de divulgação do mundo moderno" e de sua relação com a cultura literária surpreende aquele que percorre a coleção do Jornal de Letras'. A partir de 1956, o periódico passou a publicar, com assiduidade variada, notícias breves e considerações mais abrangentes e sistemáticas sobre a TV (inaugurada oficialmente, no Brasil, em setembro de 1950). Debatiam-se as qualidades intrínsecas e as possibilidades de criação da "mais nova expressão artística" - seu papel na difusão do livro, sua consolidação como novo e estimulante mercado de trabalho para o literato. As tentativas de situar a televisão no mundo das artes culminaram num poema de índole modernista, escrito pelo jornalista e poeta Dermival Costa Lima, primeiro diretor-artístico da Tupi carioca ("Elegia do camera-man", TVPoema, julho de 1960, 12).

O jornal divulgava, com entusiasmo, as iniciativas para dar "maior aproveitamento literário às possibilidades da televisão". Um exemplo egrégio: A História da Semana, que pretendia levar - ao "pequeno 'écran"" - contos, crônicas e novelas que, pela sua natureza, se prestassem à adaptação através da imagem. Entre os escritores cujas obras seriam veiculadas no programa (com 30 a 50 minutos de duração), figuravam Carlos Drummond de Andrade, Marques Rebelo, Guimarães Rosa, Aníbal 
Machado e Orígenes Lessa. O empreendimento da TV-Rio era duplamente bem-vindo: ofereceria à televisão "maiores perspectivas críticas"e abriria novas oportunidades a nossos escritores ("pois é preciso notar que os programas serão pagos") ("Televisão e literatura", outubro de 1956, 2).

Digno de aplausos era, também, o TV de Vanguarda. O programa quinzenal conduzido pelo "mestre" Cassiano Gabus Mendes, nas noites de domingo, se constituía numa das "mais sérias e honestas pesquisas de uma linguagem especificamente de TV" (Jomal de Letras, Notícias do País, julho-agosto de 1960, 3). Lançado em 1952, pela Tupi, permaneceu no ar até 1967, apresentando, ao todo, 400 espetáculos (Porto e Silva, 1981). Embora desse primazia aos clássicos da literatura e da dramaturgia estrangeira e aos filmes americanos de sucesso, levou ao ar encenações de vários textos brasileiros. A adaptação de $O$ feijão e o sonho. feita por Walter George Durst, deixou Orígenes Lessa comovido: "O autor, presenciando a sua obra no vídeo, impregnado da mesma dor humilde que lhe dera a sua imaginação, sensibilizou-se tanto que derramou uma lágrima." (Chico Vizzoni, "O feijão e o sonho", O Cruzeiro, 08 de setembro de 1956,26).

Durst alcançara, pouco meses antes, o triunfo mais marcante da história do $T V$ de Vanguarda, ao transpor para o vídeo o romance Calunga. de Jorge de Lima. O "príncipe dos poetas brasileiros", Guilherme de Almeida. não escondeu sua empolgação com o espetáculo oferecido pelo teleteatro:

Transposição para o vídeo do romance Calunga (1936). de Jorge de Lima, redundou esse admirável trabalho num espetáculo do mais vigoroso poder emotivo. Uma naturalidade (como é difícil ser natural) interpretativa, de jogo cênico, dialogação e dicção, que o nosso teatro ainda não conseguiu. Uma síntese dramática, uma continuidade e uma iluminação que o nosso cinema nunca alçançou. Uma técnica de som (fundo musical. arte dos ruídos, transmissão vocal etc.) de que o nosso rádio se pode plenamente orgulhar. A verdade tremenda que encerra violenta a substanciosa história nordestina contada pelo esplêndido Jorge de Lima e inspirados e heróicos responsáveis - todos eles - pela sua realização ante as objetivas da TV, estão a afirmar e provar que já existe, no Brasil. uma arte de vanguarda. Calunga é o seu porta-estandarte. ("Ontem, hoje, amanhã", Diário de São Paulo, 08 de março de 1956, 7)

Diante de tantos exemplos alvissareiros, como dar crédito aos sombrios prognósticos de que a popularidade da TV sepultaria o hábito da leitura? Tanto nos Estados Unidos como na Grã-Bretanha, o que se verificava era que a televisão, pelo contrário, atuava como estimulante da leitura: "A primeira coisa que um telespectador quer fazer, depois de assistir à adaptação videoteatral de um romance, é ler esse romance. caso já não o tenha feito." (Hugo Covendish, "A televisão não matou o hábito da leitura", Jornal de Letras, agosto de 1961, 9). 
A aproximação entre a galáxia de Gutenberg e a da imagem eletrônica era sacramentada, ainda, em eventos como o primeiro concurso literário realizado em parceria com a televisão. A Editora Piratininga, criadora do prêmio de 50 mil cruzeiros, contou com o apjio da TV-Record, de São Paulo; além da publicação do romance laureado, o autor receberia os direitos autorais da obra (Jornal de Letras, Rádio e TV, maio de 1958, 10). Visando a estimular o interesse de nossos "homens de ficção" (sic) pela TV, $O$ Cruzeiro, juntamente com a Tupi, lançou, em 1960, um concurso de âmbito nacional, "com prêmios substanciais em dinheiro". O objetivo, dessa feita, era criar uma literatura específica para o "veículo de divulgação artística e cultural do mais alto poder de penetração". O alargamento considerável do campo de penetração da TV decretara a necessidade de um número cada vez maior de produtores especializados. O Grande Teatro Tupi, produzido e dirigido pelo ator Sérgio Brito, era o programa que mais evidenciava a carência, entre nós, de bons argumentos para a linguagem específica do teatro pela TV. Com o propósito de manter a "nobre linha" de suas apresentações semanais, a direção vinha recorrendo, quase sempre, à adaptação de obras estrangeiras. Disposto a reverter esse quadro, Brito apelou aos colegas:

- Que todos escrevam, os autores inéditos e os consagrados. Que escrevam Jorge Amado, Rachel de Queiroz, Francisco Pereira da Silva, Henrique Pongetti, Pedro Bloch, Oduvaldo Viana Filho, Guarnieri, Jorge 108 Andrade, Ariano Suassuna e também os novos, que serão julgados em igualdade de condição com os escritores já célebres." (apud Ivan Alves, "Literatura e televisão", O Cruzeiro, 14 de maio de 1960, 20-22).

Movido por preocupações análogas, Benjamin Cattan, produtor do TV de Vanguarda, organizou, em 1964, o Primeiro Concurso de Peças Nacionais, vencido por Oduvaldo Viana Filho, com O matador, Osmar Lins, com A ilha no espaço, e Plínio Marcos, com Estória de subúrbio (Porto e Silva, 1981, 54).

De uma forma ou de outra, a TV procurava recrutar os intelectuais menos refratários à nova forma de expressão cultural, como Rachel de Queiroz - "uma das nossas escritoras que não tem preconceito da televisão", nas palavras do Jornal de Letras. O mensário fez questão de parabenizá-la por permitir que a Tupi televisionasse sua peça $O$ padrezinho santo, apresentada às $20 \mathrm{~h}$, no programa Teatro Walita ("Rachel na televisão", abril de 1958:3). ${ }^{2}$

Os elogios às aberturas da TV para a cultura literária - como a encenação, em 16 capítulos, da novela Helena, na TV-Rio - não impediam que articulistas do Jornal de Letras apontassem as limitações do veículo para converter em imagens a originalidade e o refinamento da sintaxe de certos textos: 
Não é Dom Casmurro, talhado para o cinema, situado muito além dos recursos possíveis na TV, não é Memórias póstumas de Brás Cubas, cuja fragmentação (perfeita no romance) impede, salvo graves e fundas alterações, a seqüência que o gênero exige. É - simplesmente - Helena, uma história singela, humana, tendo os indispensáveis elementos melodramáticos, dosados com segurança e - perdoem o lugar-comum inconfudivelmente machadianà. (Silvio Guimarães, "Machado de Assis. novelista de TV", fevereiro-março de 1959, 11).

Decifrar e tornar proveitosa a linguagem específica da TV era uma idéia fixa da redação do Jornal de Letras. Com intuito de sistematizar a pesquisa e a discussão, Eliseo Condé solicitou a Péricles Leal que reproduzisse o curso de Estética da Televisão, ministrado nas novas estações das Emissoras Associadas. O convite resultou numa série de oito extensos e curiosos ensaios, que contemplavam todas as facetas da arte pela imagem, mobilizando referências bibliográficas clássicas sobre cinema e estétical. Segundo Leal, a TV - considerada meramente como veículo - se constituía, em realidade, numa manifestação artística, com identidade própria. Transcorridos, no entanto. dez anos desde o lançamento da televisão no Brasil, ainda imperava um certo medo de afirmar sua autonomia ante as artes correlatas. ${ }^{3}$

Era missão do Realizador - "em que repousa toda a responsabilidade da mensagem da obra de arte na TV, em sua tríplice mister de autor (ou adaptador), diretor e produtor" - fazer com que ela não fosse apenas útil (informação, veículo de vendas etc.), mas fonte de prazer estético, obra de criação artística. Como issso era possível? Tendo-se perfeito domínio das leis e dos valores estéticos da linguagem visual, suas restrições e suas possibilidades: "(..) [O $[\mathrm{C}$ conhecimento da linguagem da TV dota o Realizador da capacidade de levar sua mensagem ao público e atingi-lo na medida exata do ideal Kantiano: 'produzindo em quem os contempla a impressão de que foram criados sem intenção, à semelhança da natureza'. Dessa perfeita união entre criador e criatura, realizador e matéria, será feita a televisão como arte." ("Televisão: sua linguagem", setembro de 1960,11). O fator social da recompensa, da posterioridade, nada disso deveria preocupar o Realizador, no "momento mais puro da criação". O que importava era produzir beleza, uma narração mais perfeita e mais bem acabada possível ("Iniciação à televisão", julho-agosto de 1960,3).

Era necessário, obviamente, um ciclópico esforço de imaginação para invocar as categorias da estética kantiana, numa análise da TV comercial, mesmo na fase tradicionalmente classificada de "elitista" pelos historiadores. Devido ao fato de, entre 1950 e 1964. o televisor se configurar num bem de consumo circunscrito a uma parcela mais abonada da população, costuma-se idealizar o perfil cultural da programação do 
período. Concorre, decerto, para esse juízo enganoso, além da memória seletiva dos pioneiros, a teima de certos estudiosos em confundir capital econômico e capital cultural, na hora de inferir o gosto da audiência. Nem só de teleteatros, ópera e balé era feita a televisão dos primeiros anos. Pululavam no vídeo, também, atrações menos requintadas: programas de prêmios; novelas policiais sensacionalistas; $A$ lô, Doçura ("o mais romântico programa da televisão"); O Direito e a Mulher ("um júri para a defesa dos problemas emocionais femininos"); Kedley $e$ Você (versão do americano "Esta é a sua vida")... Futebol, Circo Bom-Brill e Amaral Neto Comentando eram, nessa ordem, as maiores audiências de setembro de 1955 , consoante o IBOPE. ${ }^{4}$

Nem mesmo os programas mais prestigiosos estavam livres das demandas e das pressões implacáveis dos patrocinadores. Em janeiro de 57, um anunciante determinou a TV-Rio que cancelasse seu apoio publicitário ao aclamado A História da Semana. A razão da birra, segundo o Correio da Manhã, era "deliciosa": "o homem queria um breque no texto de Carlos Drummond de Andrade, para entre moça, flor e telefone, cantar loas ao seu estabelecimento. E, convenhamos, era demais querer criar breque em texto do poeta Drummond, sem mais aquela..." (Rádio e TV, 08 de janeiro de 1957, 12). O jornal carioca repisou o tema, 15 dias depois, deplorando que uma das atrações mais elogiáveis da TV não encontrasse novo patrocinador: "Será possível que se gaste dinheiro com tanta baboseira e não se queira 110 amparar um teleteatro tão bem feito, à base de originais tão bem selecionados?' (Rádio e TV, 23 de janeiro de 1957, 12).

Já no início dos anos 60, o Jornal de Letras dava os primeiros sinais de desconsolo com a programação efetivamente levada ao ar por nossas emissoras. Hábeis em capitalizar em cima do congenial mau gosto popular, os influentes patrocinadores, os publicitários e as cúpulas administrativas das tevês não se mostravam inclinados a fomentar a função esclarecedora da televisão; criavam programas cada vez piores, que, por seu turno, cooperavam para rebaixar ainda mais o padrão do gosto (Walter Alves, "A concessão dos canais de televisão", abril de 1962,8). Na coluna "Rádio e TV", Alves tornava patente que o gráfico dos sentimentos provocados pelo novo dispositivo audiovisual declinava - mês a mês - do entusiasmo ao asco. Enquanto, em todos os países do mundo, a TV arregimentara diretores, roteiristas e produtores de cinema, a nossa - lastimou o crítico se conservava desgraçadamente fiel ao rádio. Ambos eram veículos, não formàs de arte; só tinham valor quando utilizavam uma das "artes verdadeiras": a música, o teatro, o cinema, o ballet e a pantomima. Uma aliança, de resto, pouco freqüente - a programação primava pela vacuidade, pelo mercenarismo, pela falta de decência, pela inculcação premeditada de valores alienatórios e alienígenas ("Balburdia dirigida", dezembro de 1962,7 
e 10). Para desfazer essa inversão de valores (herança do pervertido sistema comercial de radiodifusão norte-americano), a única saída era a intervenção estatal ("Embrutecimento pela imagem", maio de 1962,8).

Com o golpe de 1964, o controle governamental sobre as telecomunicações se tornou, de fato, mais vigilante. O regime militar enfatizou, desde o início, o caráter estratégico da TV para a consecução do projeto nacional exposto na Doutrina da Escola Superior de Guerra (ESG) (Oliveira, 2001). O resultado da interferência estatal não foi exatamente o almejado pela crítica ilustrada: com a redução do preço e a ampliação do crediário, o número de televisores em uso no país saltou de irrisórios 2 mil, em 1950, para 760 mil, em 1960, e 4 milhões e 931 mil, em 1970 (Mira, 1995. 30); a fim de sintonizar-se com as preferências do novo público das classes $\mathrm{C}$ e D. as emissoras investiram numa linha de programação cada vez mais popular (ou "popularesca").

Por razões mercadológicas. o TV de Vanguarda e congêneres saíram da ribalta televisiva; a lista das dez maiores audiências. em junho de 1968, era composta por novelas, programas de auditórios e o Tele Catch (Israel Tabak, "Televisão, subcultura a serviço da alienação", Caderno B, Jornal do Brasil, 16 de junho de 1968,3$)$. O receio das propriedades narcotizantes e viciadoras da TV se torna, então, bastante difundido. Não só o conteúdo tosco irradiado pela TV era diagnosticado como ruinoso para a mente e para o intelecto; numa espécie de versão em negativo do determinismo tecnológico de Marshall McLuhan, afiançava-se que os problemas do veículo eram inerentes à sua própria tecnologia - " $[\mathrm{A}] \mathrm{s}$ pessoas ficam sideradas naquela tela e esquecem que há outras pessoas em volta". reclamou Vinícius de Moraes, para quem o maior pecado da televisão era contribuir para a diminuição do tempo de bate-papo ("TV/Pesquisa: Ela não é boa. Pode melhorar?", Realidade, oulubro de 1970, 16).

Ressabiado, Alceu Amoroso Lima só ligava a televisão para assistir a "documentários objetivos", sem "qualquer intenção normativa, polêmica ou novelesca"; não se tratava de preconceito contra o veículo. mas de manterse alerta para não virar escravo dele: "A TV é como álcool. Em pequenas doses estimula. Em dose maciça escraviza. E se converte num vício, como a droga. É preciso, pois, lidar com ela com muito cuidado. Como se lida com explosivos. Ou com veneno, que depende da dose. É transparente como água, mas também como nitrato de prata. É essencialmente ambivalente. Ou polivalente. E é algo que deve ser tomado em pequenas doses." (idem. 15). O homem, que desencadeara a TV, estava começando a ser devorado por ela, "a esfinge do século".

O acirramento da guerra dominical de audiência entre Chacrinha e Flávio Cavalcanti ocasionava seguidas celeumas, desagradando os militares, a Igreja, setores da "classe média do milagre" e a grande imprensa. "Todo 
mundo está discutindo o nível da nossa televisão. 'Baixíssimo', dizem uns; 'Baixíssimo', afirmam outros; 'Baixíssimo', juram terceiros. Não dou um passo sem esbarrar, sem tropeçar num sujeito indignado", escreveu Nelson Rodrigues ([13/09/1971] 1996,232), no auge da polêmica gerada pela performance, nos estúdios da Globo e da Tupi, da mãe-de-santo Dona Cacilda de Assis (que dizia receber o espírito do "Seu Sete da Lira", um exu da Umbanda).

Para Nelson, a unanimidade contra a TV não era burra - era irreal e hipócrita. Certas coisas, segundo ele, um grã-fino só ousaria revelar num terreno baldio, à luz dos archotes, na presença solitária de uma cabra vadia. Outras não diria jamais, mesmo em solo seguro. Por exemplo: o grã-fino que assistia ao Direito de nascer, ao Sheik de Agadir, a Os Irmãos Coragem, que não perdia um programa de Dercy Gonçalves, do Chacrinha, do Raul Longras, só admitiria que gostava de televisão ao médium, depois de morto (Rodrigues, s/d, 225; [13/09/1971] 1996, 234). A condição social de "pequeno burguês" - "sem nenhum laivo de grã-finismo" ou "pose de intelectual" (Nelson gostava de apresentar-se como um intuitivo) - lhe dava, em contrapartida, "descaro bastante" para confessar de peito aberto não só que assistia à televisão brasileira, como gostava dela, com todo o seu tão característico e discutido mau gosto (Rodrigues, s/d, 225).

Os leitores de $O$ Globo se espantaram, decerto, ao ver a firmeza com que Nelson interpelou o líder da cruzada por uma televisão mais virtuosa - o

112 ministro da Comunicação, Hygino Corsetti, que ventilara a hipótese de cassar a concessão das emissoras que insistissem com o "sensacionalismo" e a "baixaria". O cronista classificou de "uma selva de equívocos" o pronunciamento de sua excelência sobre a programação das emissoras brasileiras. Como de hábito, Nelson abusou do sarcasmo para desacreditar seu adversário: a verdade inapelável e fatal - insinuou - era que o "sr. ministro" só pudera iluminar a todos com uma "minuciosa análise reflexiva sobre as nossas TVS (sic)", porque, no fundo, fazia parte dos oito milhões de brasileiros que passavam os dias e as noites diante da telinha; era, entre quatro paredes, um telespectador atento, fanático, "dos que vêem novela, e tanto as vê que acha algumas de uma extensão fatigante" (Rodrigues, [13/ 09/1971] 1996, 232).

Numa linha de argumentação que a essa altura já soa bastante familiar, Nelson costumava afirmar que nossa televisão era o espelho de nosso povo: "Evidentemente, você não vai investir bilhões numa TV para que o Proust diga: 'Está ótimo. Tem bom gosto"' ("Eu sou um ex-covarde", Veja, 04 de junho de 1969, 5; consultar, ainda, "Telenovela é uma epidemia nacional", Veja, 07 de mais de 1969, 29; Rodrigues, s/d. 119; Rodrigues, 1996, 233). Aos "radicais" que, seguindo o ministro Corsett1, repetiam a ladainha "precisamos mudar a televisão", ele replicava que mais correto seria "mudar o povo" (Rodrigues, [13/09/1971] 1996, 234). 
Nelson já fazia parte da história da televisão brasileira, quando se manifestou, de forma enfática, em sua defesa ${ }^{55} \mathrm{O}$ celebrado criador de Vestido de noiva integrou a primeira mesa-redonda sobre futebol da TV brasileira (quiçá, da TV mundial). O sucesso na "Resenha Facit" o conduziu ao "Noite de gala", carro-chefe da TV Rio, onde apresentou "Cabra vadia" quadro sui generis

de entrevistas, realizado num cenário que simulava um terreno baldio, com caprinos de verdade pastando e tudo mais. Nelson escreveu, também, a telenovela "A morta sem espelho" (1963), perseguida pela censura e narrada pelo próprio autor, com sua inconfundível entonação sepulcral; tentou o gênero mais duas vezes, com "Sonho de amor" (1964), pretensa adaptação de O tronco do ipê, de José de Alencar, e "O desconhecido"

(1964), história de um neurótico de guerra que fugia do manicômio (Clark, 1991, 151-154; Castro, 1992, 332-333, 341-342, 345-346; Annette Schwartsman, "Juiz condenou Nelson ao fim-de-noite", Folha de S. Paulo, tvfolha, 16 de abril de 1995, 4; Esquenazi, 1996, 29-30, 98-99).

Das declarações anteriores, depreendemos que ele estava solidamente convicto de que o veículo que conhecia tão bem era - e deveria ser - um reflexo do gosto popular, das preferências da massa ignara. Ao contrário do ministro Corsetti e de tantas outras autoridades governamentais e intelectuais, Nelson não via problema algum, inclusive, em utilizar a medição do Ibope como sismógrafo dos anseios da audiência: “(...) [E]ssas pesquisas são imprescindíveis. Eu diria mesmo que o pior cego é o que não vê a utilidade de tais pesquisas. (Foi, naturalmente, um lapso de sua excelência)." (Rodrigues, [13/09/1971] 1996, 233).

Quando o assunto era televisão, Nelson (polêmico por cálculo, por instinto) se indispunha com gente de todas as divisões ideológicas. Sua perspectiva crítica diferia das posições tradicionais a respeito da natureza, do papel e da influência dos modernos meios de comunicação: em linhas gerais, enquanto a direita credita às falhas morais e ao congenial (mau) gosto do vulgo o baixo nível da cultura de massa (enxergando na mesma, não raro, um perigo às estruturas tradicionais de autoridade, um ultraje à família, um estímulo à irresponsabilidade no lar e no trabalho, uma indutora automática de delitos criminais variados), a esquerda atribui esse baixo nível às duras condições de vida na sociedade capitalista e ao empenho da elite para domesticar uma população potencialmente insubmissa, explorando seu desejo natural pcr recreação com o intuito de mantê-la indiferente aos destinos da sociedade, preservando, assim, o status quo.

Nelson concordava que a televisão brasileira era de um mau gosto profundo, reflexo, por sua vez, do mau gosto da multidão insensível ou refratária à Cultura; não via, porém, nenhum mal nisso - seja do ponto de vista moral, político ou estético. Ele reagiu, com veemência, por exemplo, 
contra a "ditadura do Juizado de Menores" que escorraçara as novelas do horário nobre para as onze horas da noite. Do ponto de vista psicológico argumentou - era uma asneira imaginar que os folhetins pudessem produzir "uma geração de perigosíssimos gangsters juvenis". Pelo contrário: o efeito catártico lhes conferia o salutar papel de higienizador mental. Do ponto de vista estético, ironizou que chegava a ser "sublime" a idéia de impor o bom gosto "a pauladas". O pior é que os "assassinos da telenovela" estavam apenas começando a agir; como uma coisa puxa a outra, não tardaria para que as marchas e os sambas fossem igualmente expulsos do horário nobre (Rodrigues, [25/09/1964] 1996,47-48). Do ponto de vista político, Nelson atribuía à dificuldade de respeitar e compreender o gosto popular (Chacrinha, escola de samba, Fla-Flu, sexo) uma das principais razões do fracasso das esquerdas no Brasil, mais solitárias, mais insuladas do que um Robinson Crusoé sem radinho de pilha (Rodrigues [27/01/1968] 1993a, 120).

Nunca é demais lembrar que, nos anos 60 , seduzidos pela possibilidade de falar às grandes massas, artistas de esquerda se dispuseram, sim, a deixar os preconceitos de lado, e tentar modificar a televisão, atuando estrategicamente dentro dela (Ortiz, 1988; Ridenti, 2000). "A televisão é ruim assim porque os intelectuais deixaram que ela ficasse assim. E ela está aí para ficar. Quem quiser mudar que entre na briga", conclamou o dramaturgo, romancista e ator Plínio Marcos ("Telenovela é uma epidemia nacional", Veja, 07 de maio de 1969,29). "Tem muito intelectual metido a bacana, que 114 pensa virar estátua, que se preocupa com o que a História vai dizer dele. Fica sonhando com a academia e acha televisão um negócio sujo. Estes vão ficar falando sozinhos. Pra mim, o negócio é entrar na briga. E partir pro pau!" (idem, ibidem).

$\mathrm{O}$ ingresso na TV se harmonizava com a tese, sempre sustentada pelo escritor, de que mais importante que a "cultura" do "artista de elite", das "pessoas herméticas que não falam uma linguagem que seja compreendida por todos", era a "popularidade" (medida pela fácil comunicabilidade com o público):

[N]ão adianta absolutamente nada a cultura enrustida. (...) Neste momento, nós temos grandes escritores, grandes artistas mesmo e grandes atores que não conseguem chegar junto a seu povo, não é? E qualquer babaquara da Globo chega violentamente... (...) Tenho certeza, por exemplo, de que se uma vanguarda não caminhar junto do povo acaba até servindo a quem detém o poder. É preferível caminhar no nível do povo, não fazendo concessões de idéias, mas fazendo concessões na forma para atingi-lo. (Steen, 1981, 256).

Assim também pensavam Paulo Pontes e Oduvaldo Vianna Filho. Intelectuais ligados ao PCB, eles desembarcaram, em 1S $\$$ ?, na TV Tupi. A razão foram as dificuldades de sobrevivência no teatro, em virtude dos 
problemas com a censura, que acabaram redundando no término do Grupo Opinião, do qual eram fundadores. Juntos, os dois escritores efetuaram uma sensível reformulação na grade da Tupi: criaram o Festival Universitário, o Festival de Música de Carnaval, remodelaram o programa infantil do Capitão Aza e o programa de Bibi Ferreira, o "Bibi ao vivo", no qual introduziram um miniteatro, de 12 minutos, previamente gravado sob a direçāo de Sérgio Brito.

O projeto de uma nova programação, encomendado pe!o diretor-geral da Tupi, Almeida Castro, realçava o papel primordial das telenovelas na guerra de audiência. O caminho a seguir era o realismo - um modelo narrativo voltado para as relações reais que um homem estabelece em sua vida e que criara as histórias mais ricas que se conhece e mais apropriadas à televisão (Moraes. 1991, 220-222; Maria Célia Teixeira, "Guerra de audiência não é de hoje", Jornal do Brasil, Idéias. 02 de dezembro de 2000, 3). O colega Dias Gomes era citado como exemplo de um esquema dramático realista ajustado ao gosto popular. E é, seguramente, na trajetória profissional desse autor que devemos concentrar nossa atenção, se quisermos captar todas as nuanças da melindrosa e complicada convivência entre as ambições dos artistas de esquerda e as necessidades e as preferências dos produtores culturais e da audiência de massa.

A primeira incursão do literato baiano na TV é pouco conhecida. Por volta de 1953, alastrava-se pelo Brasil uma verdadeira caça às bruxas, versão nacional do macarthismo norte-americano. Devido a uma viagem à União Soviética, Dias Gomes perdeu o emprego na Rádio Clube do Brasil e ficou durante um ano sem poder escrever usando o próprio nome em qualquer veículo de comunicação. Para sua sorte, no entanto, a TV Tupi (única situada no Rio de Janeiro, à época) não tinha autores contratados e comprava programas avulsos; Dias passou, então, a escrever peças policiais, shows e tudo mais que compusesse a grade da emissora. sob o disfarce do nome de dois amigos e dc esposa, Janete Clair (Silva Júnior, $2001,86)$.

Autor teatral já renomado (graças à repercussão, em 1960, da montagem de $O$ pagador de promessas, adaptada para o cinema. com sucesso, por Anselmo Duarte, em 1963), Dias Gomes retornou à TV, em 1969 - mais uma vez, por questão de sobrevivência. Sem emprego e com as peças $O$ berço do herói e $A$ invasão interditadas, aceitou o convite da Rede Globo para escrever telenovelas, ao lado de Janete Clair. A idéia de levar sua temática teatral a uma platéia gigantesca - a mais heterogênea que já tivera, composta de elementos de todas as classes sociais, do intelectual ao marginal - The soou bastante sedutora ("Do Pagador de Promessas ao BemAmado: Dias Gomes", Opinião. 26 de fevereiro a 04 de março de 1973, 19 ; Pecegueiro, 1980, 32; Gomes, 1998, 255; Ridenti. 2000, 329: Silva Júnior, 
2001,84). Nem mesmo a censura, o caráter industrial e as condições pouco convenientes de recepção retiravam da teledramaturgia, na sua opinião, c potencial crítico (Silva Junior, 2001, 93-94).

A primeira tarefa de Dias, porém, na emissora do Jardim Botânico, foi inglória: concluir a adaptação do folhetim italiano dó século XIX $A$ ponte dos suspiros, após a saída de Glória Magadan. A fim de "aliviar a consciência", ele introduziu, "sutilmente", no "enredo alienante", uma crítica à deposição de João Goulart, e à esperança de tempos melhores (Gomes, 1998, 258). Uma ardileza insuficiente para dar cabo do constrangimento do dramaturgo, que assinou a obra com o pseudônimo de Stella Calderon.

A partir daí, Dias Gomes procurou levar adiante seu projeto de renovação da telenovela, fundamentado numa série de "experiências temáticas, formais". A proposta - endossada por Daniel Filho, então diretor de produção da Globo - era descartar o formato cubano-mexicano convencional dos folhetins melodramáticos e ambientados em paragens exóticas da Espanha e do Caribe e promover uma gradual aproximação entre a teledramaturgia e o "universo real" do telespectador brasileiro. Verão Vermelho (1970) - primeira novela assinada pelo autor com o próprio nome (no contrato com a Globo, havia uma cláusula que lhe garantia um aumento, se assim procedesse) - era ambientada no interior da Bahia, no tempo dos coronéis, e tratava da questão da terra e dos tipos populares regionais: "O 116 visual já era brasileiro, embora tivesse a aventura e o romance do folhetim, porque não podia me desligar abruptamente disso. Mas já era uma temática totalmente nossa, um linguajar nosso, com raízes nossas." (Silva Júnior, 2001, 89). Assim na Terra como no Céu (1970-1971) pretendia mostrar o jeito de ser carioca, com as garotas de praia e os cafajestes de Ipanema; Dias se orgulhava da heresia que cometera logo no vigésimo capítulo, ao matar a heroína da novela, sabendo que iria desgostar 95 por cento do público: "Eu pretendia provocar nele uma atitude crítica em relação à novela, o que consegui. As cartas insultuosas que passei a receber, aos montes, criticavam a sociedade que eu estava mostrando, supondo que estavam criticando o meu trabalho." ("Do Pagador de Promessas ao Bem-Amado", Opinião, 26 dé fevereiro a 04 de março de 1973, 19).

A aposta no bom-humor, que distanciava a novela do vale de lágrimas do folhetim tradicional, foi repetida em Bandeira 2 (1972) - "a melhor novela já apresentada pela televisão brasileira", na opinião (amplamente compartilhada) de Veja ("A novela quase na maioridade", 12/07/72, 80-82). O público aplaudira a experiência, sustentando um lbope inédito, às $22 \mathrm{~h}$, de $55 \%$, no Rio de Janeiro (até então, os índices não haviam passado dos $30 \%$, no horário); Dias Gomes amargou, porém, uma derrota no capítulo final: a Censura exigiu a morte do protagonista Tucão - o bem tinha quetriunfar sobre o mal. 
Com a auto-estima tonificada ainda mais pelo sucesso de público e de crítica de $O$ Bem-Amado, Dias envereda suas especulações acerca das possibilidades criativas da telenovelas até o que ele chama. com propriedade, de "revelador terreno do absurdo":

"Seria possível realizar uma verdadeira obra-de-arte na televisão? Principalmente se estendesse o conceito a uma arte de massas? Ou haveria limitações de ordem estética intransponiveis? Essas limitações não seriam mais de ordem conjuntural e extraveículo, localizadas principalmente na forma e nos objetivos comerciais de produção?" Perguntas para as quais até aquele momento, não tinha resposta. Entendia o caráter efêmero da telenovela, sua linearidade, sua horizontalidade, que rejeitava reflexos profundos, em que pesasse seu fantástico poder de denúncia e abrangência nunca alcançado por qualquer outro meio de expressão. Mas eram limitações que the recusavam o passaporte para o meio das artes. Em suma. entrando no revelador terreno do absurdo, em condições ideais, Shakespeare redivivo teria podido mostrar ali seu gênio? Seriam pertinentes todas essas dúvidas ou, quem sabe, eu estava apenas tentando me justificar e aplacar minha consciência culpada? (Gomes, 1998, 275-276)

A despeito das boas intenções e de pareceres favoráveis, a marcante passagem de Dias Gomes pela TV suscitou resistências similares às provocadas por seu trabalho no rádio, nos anos 40 - "Escrever para o rádio naquela época não era exatamente uma profissão artística, digamos assim" (Silva Junior, 2001, 83). Os literatos que malbaratavam seu talento, nos meios de comunicação de massa, submetendo-se a um trabalho feito às pressas e às demandas e aos veredictos dos patrocinadores, eram rotineiramente alvo de condenação ou de compaixão: "Dias Gomes, como tantos outros, tem de sentar-se à máquina pondo a alma de lado, para produzir, obrigado, coisa pior do que o que pode escrever. satisfazendo exigências e 'forças ocultas' não reveladas mas ao alcance de quem queira ver." (Walter Alves, Jornal de Letras, "As lições do 'Pagador", junho de 1962,6).A busca da popularidade na indústria televisiva resultaram, ainda. em reações de "intelectualóides", de "idiotas" que achavam que o companheiro estava cometendo uma espécie de traição. aderindo ao sistema, à alienação que representava a telenovela - sobretudo, quando produzida pela suspeitável TV Globo (Silva Júnior, 2001, 88). Na maior parte dos casos, Dias Gomes respondia a essa patrulha ideológica repisando a natureza catequizante e ligeiramente subversiva de sua passagem pela Globo; às vezes, entretanto, adotava uma atitude mais realista, relembrando a escassez de oportunidades de trabalho absolutamente idôneo, durante os Anos de Chumbo (Ridenti, 2000, 327).

Todavia, o próprio escritor, na sua correspondência pessoal ou nas anotações de seu diário, se revela mais desgostoso com o trabalho na 
televisão do que externava em declarações públicas. No diário que o autor manteve por quase três anos, entre agosto de 1959 e maio de 1962, a ambição de realizar-se no teatro é assunto recorrente: "Preciso me realizar como autor. Parece que reencontrei o meu caminho. Devo ter força de vontade para não deixar que me afastem dele novamente. Recebi um pedido de Aimée para escrever uns programas de televisão para ela. Não vou aceitar. Chega de mediocrizar o meu nome." (08/11/1959; em "Uma vida aberta", $O$ Globo, Segundo Caderno, 03/06/2001, 6). Em carta enviada a Jorge Amado, em fevereiro de 1992, o dramaturgo lamentava não poder deixar a TV de lado para dedicar-se a um romance: "Poucos são os que, como você e Zélia, podem viver de fazer o que gostam. Eu passei pelo menos um terço de minha vida fazendo o que não gostava. E continuo. Como um garoto que detesta jiló, mas a mamãe ameaça 'se não comer jiló não vai brincar'. E ele é obrigado a enfiar o jiló goela abaixo. Eu vivo comendo jiló." (idem, ibidem).

Leitor de Ponson du Terrail, Eugène Sue, Michel Zevaco, Xavier de Montepin, Alexandre Dumas pai; autor de Meu destino é pecar, Escravas do amor, entre outros folhetins assinados com o pseudônimo de Suzana Flag ou Myrna, Nelson Rodrigues não manifestava grande entusiasmo pela modernização da telenovela empreendida (a contragosto ou não) por Dias Gomes e outros autores com ambições revolucionárias no plano político e/ ou estético. No seu entender, a televisão (como, de resto, toda a indústria 118 cultural) era sinônimo de diversão, passatempo, fortes emoções e é só. A missão da telenovela não era expor as chagas do país, conscientizar politicamente as massas, mas entreter a santa e abnegada audiência. Novela progressista era, na sua avaliação, um oximoro - tratava-se de um gênero de índole conservadora, que funcionava como válvula de escape para a sensaboria cotidiana e para as tensões sociais: "A novela é sobretudo uma fuga. Como a realidade é muito insatisfatória, a novela representa o sonho cotidiano para muita gente. É um repouso." "'De rainhas loucas, bemamados, irmãos coragem, etc, etc", Opinião, 27/08 a 03/09 de 1973, 20). Tampouco cabia à TV mediar a alta cultura para o grande público: a intenção de importar o modelo cultural europeu (notabilizado pela televisão pública britânica) não era apenas precipitada; representava uma traição a certo instinto de nacionalidade expresso pelas emissoras brasileiras - com suas vulgaridades sublimes, com sua lealdade a formas narrativas $\mathrm{e}$ espetaculares de comprovado apelo popular no correr dos séculos (sobretudo, na América Latina) ("Telenovela é uma epidemia nacional", Veja, 07 de maio 1969, 29; "Eu sou um ex-covarde", Veja, 04 de junho de 1969, 5; "De rainhas loucas, bem-amados, irmãos coragem, etc, etc.", Opinião, 27 de agosto a 03 de setembro de 1973, 209).

Atuando como advogado de Chacrinha, no caso do "Seu Sete da Lira", 
o autor repisou a denúncia das imposturas intelectuais que norteavam a crítica televisiva: "Aristóteles havia de achar uma graça infinita no nosso Abelardo Barbosa. Claro, porque ele não precisa fingir inteligência." (Rodrigues, [13/09/1971] 1996.235) Nelson Rodrigues não foi c primeiro nem o único a conduzir Chacrinha ao trono. Como é de conhecimento geral, "o velho palhaço" foi eleito um dos gurus do tropicalismo, movimento artístico e comportamental que eclodiu no eixo Rio-São Paulo em 1967, capitaneado por Caetano Veloso e Gilberto Gil. Antes deles, outro intelectual da velha guarda como Nelson não escondera sua admiração pelo comunicador. Em 02 de abril de 1966, Manchete promoveu, dentro da série Diálogos Impossíveis, o encontro entre Chacrinha e Rubem Braga "homens de mundos aparentemente diferentes". mas "escravos ambos do povo". A conversação, "que a princípio parecia difícil de se estabelecer", acabou esticando-se por horas a fio na cobertura do "sabiá da crônica", em Ipanema. Uma conversa longa e franca a respeito de temas variados (de Roberto Carlos a Nossa Senhora da Penha), mas em que prevaleceu a rasgação-de-seda e a troca de idéias acerca da arte de cativar o gosto popular.

Será mera coincidência que os elogios à Chacrinha tenham partido de homens de letras que se notabilizaram por sua atuação em gêneros não auráticos. cuja expansão está ligada ao aparecimento dos meios de comunicação de massa? Decerto que não. "Há homens que são escritores e fazem livros que são verdadeiras casas, e ficam. Mas o cronista de jornal é como o cigano que toda noite arma sua tenda e pela manhã a desmancha, e vai", meditou Rubem Braga, a respeito de seu ofício (1978a, 153). A consciência da própria efemeridade, a humildade de abrir as portas do isolamento criativo para atender os anseios explícitos ou tácitos do leitor, seu freguês, positivamente deixavam o cronista mais sensível, em alguma medida, à preocupação e à habilidade dos profissionais de TV para afinar-se com as flutuações do Ibope.

No caso específico de Braga, os pronunciamentos favoráveis à TV não eram apenas fruto do entendimento e da solidariedade. Segundo o biógrafo José Castello (1996, 152-154), o cronista era um daqueles telespectadores fanáticos a que se referia Nelson. Não perdia uma partida de futebol ou uma só edição do programa Inglês com Música, da TV Educativa (abaixava o volume do televisor, interessado menos no estudo do idioma do que na professora...). Muitas vezes, telefonava tarde da noite para o amigo Paulo Garcez, pedindo socorro: "A TV Globo não está pegando. Não posso ver minha novela" (idem. 150). Mesmo quando subscrevia algumas das condenações mais comuns à televisão (prejudicar a leitura de livros. por exemplo), fazia questão de ressaltar, com temura altiva, uma faceta positiva da "corujinha da madrugada": a grande distração, o grande consolo. a 
grande companhia aos doentes, aos velhos e a outras criaturas solitárias... "Ela instala dentro de sua toca humilde o tumulto e o frêmito de mil vidas, a emoção, o suspense, a fascinação dos dramas do mundo." (Braga, 1978b, 318-319).

Telemaníaco, Rubem Braga abominava comparecer aos estúdios para debates e entrevistas. A razão era a mesma alegada por Raquel de Queiroz: timidez. A julgar pelo depoimento de Henrique Pongetti, os dois não sabiam o que estavam perdendo. Certa ocasião, ele foi ao Chacrinha receber uma homenagem. O produtor da TV the prometera uma "propaganda eficaz" de $O$ carregador de lembranças, seu mais recente lançamento literário, e isso logo venceu a hesitação inicial - hesitação causada, bem entendido, pela preguiça de descer e subir a serra de Petrópolis, não por qualquer consideração sobre o nível intelectual do programa... Metido num "sóbrio" uniforme do Flamengo, Chacrinha disse muitas coisas lisonjeiras sobre o escritor - "e tão sério e tão respeitoso como um acadêmico recebendo outro na ABL". Sem demora, Pongetti descobriu que o comunicador era um "veículo publicitário de inestimável valia"; era capaz de vender de tudo, até mesmo livro, o mais supérfluo artigo à venda no Brasil: "Meu livro reagiu muito bem até em zonas de reconhecida avareza mental, e não se trata propriamente de uma obra popularesca (...)."("Ir ao Chacrinha", Manchete, 24 de abril de 1971,59).

Acostumado aos holofotes, Nelson também visitou Chacrinha, na TV

120 Globo. Aceitou o prêmio de maior cronista esportivo de jornal, com o ar de quem recebe um Nobel. Ficou pasmo com a multidão no estúdio: duas mil pessoas num espaço que daria para quinhentas. E como Chacrinha era amado, ferozmente amado! "Nunca ninguém me deu, na vida real, tamanha sensação de onipotência. Se mandasse o auditório atear fogo às vestes como uma namorada suburbana (ou um monge budista), seria um fogaréu unânime." (Rodrigues, [22/01/1968] 1993, 105). Alheias ao clamor nacional contra o milionário ordenado do apresentador, as macacas-de-auditório sabiam reconhecer nele o "artista maravilhoso", "formidável", "um gênio" no seu métier.

Nelson - vale assinalar - nem sempre era tão positivo na defesa das predileções e do julgamento da audiência. Todo o discurso a favor do relativismo cultural - "há uns trezentos bons gostos" (Rodrigues [13/09/ 1971] 1996, 235) - e da necessidade de auscultar e acatar o gosto do público caía por terra quando o assunto era o Teatro. Este, no seu pónto de vista, permanecia indigno de ostentar a condição de grande arte justamente por não pressupor uma concepção imaculada e uma fruição solitária, reverente, análoga à do romance e à do soneto, tendo de submeter-se aos caprichos da platéia (Rodrigues, [1967] 1993b, 156-157; ver, também, Rodrigues [16/05/ 1968] 1993a, 247; Rodrigues, [18/03/1971] 1995, 190). Amargurado, o 
dramaturgo sonhava com uma representação utópica, para cadeiras vazias: "Só seria autor, atriz ou ator, aquele que tivesse disposto a trabalhar para ninguém. (...) Comecei a achar que também as igrejas vazias são as mais belas. O que comprometia e debilitava a fé eram os fiéis." (Rodrigues [1967] 1993b, 157).

Não há dúvida de que a hostilidade de Nelson contra as "duzentas senhoras gordas comedoras de pipocas" da platéia teatral era, em larga medida, uma resposta à recepção escandalizada ou pouca atenciosa às suas peças. Por ironia do destino, no exato instante em que ele redigia suas crônicas, memórias e confissões, a televisão brasileira incrementava as mudanças que visavam a atender nem tanto o "bom-gosto-sem-tostão-dosintelectuais" (Rodrigues [13/09/1971] 1996, 235), as plataformas políticas mais ambiciosas dos artistas de esquerda, mas o bom-gosto do público de classe média freqüentador displicente e desconceituado de teatro e consumidor (não só) de pipocas (constituindo-se, por consequiência. num agente importantíssimo para a efetivação do projeto desenvolvimentista do governo militar e das emissoras de TV). Em outras palavras: após muito alvoroço, muita palpitação, prevaleceu, em detrimento dos discursos mais extremados que apregoavam a TV progressista ou a TV cultural sob a interferência direta do Estado, a saída honrosa e conciliatória daqueles que propugnavam por uma TV comercial, voltada para a informação e para o entretenimento mais prudente e pudico - sem baixarias, cafajestadas, histerias, mundo-canismos e outras concessões à gente sem classe.

A iniciativa de eliminá-los partiu de quem, de forma mais sistemática, levara a cafonália ao ar. Com uma saúde financeira invejável, já se sedimentando como rede nacional, a TV Globo optou, no começo dos anos 70 , por uma nova filosofia de programação que, além de evitar as constantes altercações com os militares, atingisse um público mais qualificado, mantendo o que já se tornara cativo (os $60 \%$ das classes C/D). "Já não interessava à Globo dar 90 por cento de audiência com programas como o Casamento na TV', explicou Walter Clark $(1991,232)$. "Era melhor dar 70 por cento com uma novela adaptada de um livro de Jorge Amado, por exemplo, que daria prestígio à emissora."

Fonte inesgotável de tramas telenovelescas globais, Amado costumava não interferir no trabalho de roteiristas e diretores, nem assistir ao produto final de suas versões. Qualquer adaptação de obra literária, no seu entender, era uma "violência contra o autor"; mesmo a lendária Gabriela (1975) adaptada por Walter George Durst e dirigida por Walter Avancini o deixou insatisfeito: "Eu parei de ver no terceiro ou quarto capítulo porque eles fizeram o Nacib saber que não era brasileiro. No livro ele nunca descobre isso. Eu me senti ofendido. (...) Para não passar por essas coisas, agora eu prefiro nem começar a ver as adaptações." (Cadernos de 
Literatura Brasileira, $\mathbf{n}^{\circ} 3$, março de 1997, 46). Em que pese a angústia da traição, o escritor reconhecia que tais infidelidades ao texto original eram inevitáveis (Pecegueiro, 1980, 25). No final das contas, o ganho cultural (e financeiro) da transposição de suas histórias para a telinha compensava os possíveis desacatos à autoridade autoral: veja, por exemplo, Gabriela, adaptada para a televisão: quando do lançamento da novela da Globo, havia-se vendido no Brasil cerca de 600 mil exemplares do romance (de 1958 até 1975). A novela atingiu vinte e cinco milhões de telespectadores (além de ter feito vender mais de 80 mil exemplares do livro). Em Portugal, quando Gabriela foi posta no ar, a Editora Europa América havia vendido $40 \mathrm{mil}$ exemplares do livro; durante a exibição da novela, vendeu mais 51 mil exemplares. Essa novela da Globo levou os personagens, os ambientes e certas idéias de meu romance a milhões de pessoas no Brasil, na Europa e na África. Em Angola, a percentagem de analfabetismo sobe a 90\%; só mesmo a televisão poderia levar às massas angolanas meus personagens $\mathrm{e}$ os problemas colocados em meu nome." (Steen, 1982, 63).

Essa postura pragmática (resignada?, conformista?) se tornou mais ou menos canônica, entre os literatos, a partir dos anos 80. Da parte da crítica, o fato mais notável é o arrefecimento das tentativas, comuns nos anos 50, de submeter a televisão a uma análise no altiplano da estética. A visada literária e humanista dos "homens de ficção" foi substituída, em regra, pelo jargão dos comunicólogos. O horizonte de expectativas se estreitou;

122 ninguém mais ousa reprisar a expressão "oitava arte". Como evidencia Décio Pignatari $(1988,487)$, ostensivas declarações de amor à TV parecem coisa de um passado imemorial: "As pessoas se apaixonam pelos quadrinhos, pelo rádio, pelo cinema, pelo rock - mas ninguém se apaixona pela televisão. TV não é questão de obsessão, paixão ou afeição: é questão de vício. Vicia-se pela televisão, como se vicia em açúcar, fumo, maconha, coca e outros da área farmaco-dependente."

Resta saber, apenas, como o poeta e ensaísta classificaria os colegas de profissão que, de nariz torcido ou não, seguem abastecendo de histórias esse mercado vicioso...

\section{Referências Bibliográficas:}

BRAGA, Rubem. "Manifesto". In: 200 crônicas escolhidas - as melhores de Rubem Braga, p. 152-154. Rio de Janeiro: Record, 1978a.

. "Ela tem alma de pomba". In: 200 crônicas escolhidas - as

melhores de Rubem Braga, p. 318-319. Rio de Janeiro: Record, 1978b.

BRANTLINGER, Patrick. Bread \& circuses - theories of mass culture as social decay. Ithaca \& London: Cornell University Press, 1983.

CASTRO, Ruy. O anjo pornográfico: a vida de Nelson Rodrigues. São

Paulo: Companhia das Letras, 1992.

CLARK, Walter. O campeão de audiência. São Paulo: Best Seller, 1991. 
ESQUENAZI, Rose. No túnel do tempo: uma memória afetiva da televisão brasileira. São Paulo: Artes e Ofícios, 1993.

GOMES, Dias. Apenas um subversivo. Rio de Janeiro: Bertrand Brasil, 1998. MIRA, Maria Celeste. Circo eletrônico - Sílvio Santos e o SBT. São Paulo: Loyla/Olho D’Água, 1995.

MORAES, Dênis de. Vianinha: cúmplice da paixão. Rio de Janeiro:

Nórdica, 1991.

OLIVEIRA, Lúcia Maciel Barbosa de. "Nossos comerciais, por favor!" : a televisão brasileira e a Escola Superior de Guerra. São Paulo: Beca, 2001.

ORTIZ, Renato. A modema tradição brasileira. São Paulo: Brasiliense, 1988.

PECEGUEIRO, Alberto (coord.). Melhores momentos. A telenovela

brasileira. Rio de Janeiro: Rio Gráfica, 1980.

PEIXOTO, Fernando (org.). Vianinha: teatro, televisão, polírica. São Paulo: Brasiliense, 1983.

PIGNATARI, Décio. "O paleolhar da televisão". In: NOVAES, Adauto (org.), O Olhar, p. 487-492. São Paulo: Companhia das Letras, 1988.

PORTO E SILVA, Flávio Luis (coord.). O teleteatro paulista nas décadas de 50 e 60. São Paulo: Secretária Municipal de Cultura, 1981.

RIDENT1, Marcelo. Em busca do povo brasileiro: artistas da revolução, do CPC à erada TV. Rio de Janeiro: Record, 2000.

RODRIGUES, Nelson. A cabra vadia. Rio de Janeiro: Livraria Eldorado, s/d. Depoimento. In: Depoimentos V, p. 111-135. Rio de Janeiro:

Serviço Nacional de Teatro, 1981.

Letras, 1993a.

A menina sem estrela - memórias. São Paulo: Companhia das

. O óbvio ululante - primeiras confissões (crônicas). São Paulo:

Companhia das Letras, 1993b.

O reacionário: memórias e confissões. São Paulo: Companhia

das Letras, 1995.

O remador de Ben-Hur-confissões culturais. São Paulo:

Companhia das Letras, 1996.

SILVA JÚNIOR, Gonçalo. Pais da TV - a história da televisão brasileira contada por - São Paulo: Conrad Editora do Brasil, 2001.

STEEN, Edla Van. Viver \& escrever, v. 1. Porto Alegre: L\&PM, 1981.

- Viver \& escrever, v.2. Porto Alegre: L\&PM. 1982.

\section{Notas:}

'Mensário criado, em 1949, no Rio de Janeiro, por Elysio. João e José Condé. Integraram seu corpo de redatores e seu conselho fiscal expoentes da arte e da crítica literária: Brito Broca. Alvaro Lins, Carlos Drummond de Andrade, José Lins do Rego, Manuel Bandeira, entre outros.

${ }^{2}$ A relação entre Rachel de Queiroz e a TV só não era mais estreita. segundo a autora, graças a um mal que vinha de longe: "esse medo do microfone, 
esse temor danado do olho cego da câmara". Apenas o acanhamento a impedira de aceitar o convite do amigo João Condé para participar de sua "formidável série" de Arquivos Implacáveis, na TV-Tupi - "programa que vem satisfazer àquela necessidade inadiável de se estabelecer contato entre as classe escreventes e legentes do País, visando melhor entendimento, compreensão e amor recíprocos." " "Microfone e Televisão", O Cruzeiro, 10 de dezembro de 1955:130).Eldorado, s/d.

${ }^{3}$ Para Rachel de Queiroz, por exemplo, a TV, na sua concorrência simultầnea com o cinema e o teatro, vencendo-os em vários pontos, sofria, entretanto, de dois handicaps: "do cinema ela não dispõe da mobilidade, a espécie de ubiquiidade da câmara cinematográfica, que praticamente não conhece limitações de tempo e do espaço. Reduzida no tempo à ação atual, no espaço às três paredes do palco de estúdio, a televisão faz, realmente, teatro fotografado, mas - e aí vem, o segundo handicap - sem contar com o elemento básico do teatro: a presença real, o contato 'vivo' dos atores com público. Pois a imagem refletida em miniatura nas telas da TV, por mais perfeita e expressiva, por mais que a saibamos real e atual sempre a recebemos como uma figura de filme" (O Cruzeiro, Última Página, 11 de julho de 1953:98). Vale observar que a autora reflete sobre uma TV ainda mais tecnologicamente precária que a abordada por Péricles Leal.

${ }^{4}$ As informações e os comentários sobre a programação foram recolhidas nas páginas de $\mathrm{O}$ Cruzeiro.

12450 celebrado criador de Vestido de noiva integrou a primeira mesa-redonda sobre futebol da TV brasileira (quiçá, da TV mundial). O sucesso na "Resenha Facit" o conduziu ao "Noite de gala", carro-chefe da TV Rio, onde apresentou "Cabra vadia" - quadro sui generis de entrevistas; realizado num cenário que simulava um terreno baldio, com caprinos de verdade pastando e tudo mais. Nelson escreveu, também, a telenovela "A morta sem espelho" (1963), perseguida pela censura e narrada pelo próprio autor, com sua inconfundível entonação sepulcral; tentou o gênero mais duas vezes, com "Sonho de amor" (1964), pretensa adaptação de $O$ tronco do ipê, de José de Alencar, e "O desconhecido" (1964), história de um neurótico de guerra que fugia do manicômio (Clark, 1991, 151-154; Castro, 1992, 332-333, 341-342, 345-346; Annette Schwartsman, "Juiz condenou Nelson ao fim-de-noite", Folha de S. Paulo, tvfolha, 16 de abril de 1995, 4; Esquenazi, 1996, 29-30, 98-99).

\section{Palavras-chave}

1. Televisão

2. Escritores

3. Mercado 